\title{
Implication of Regulation Authorities on the Efforts to Accelerate the Eradication of Corruption
}

\author{
Sukmareni, ${ }^{1 *}$ Elwi Danil2 ${ }^{2}$ Ismansyah' ${ }^{2}$, Zainul Daulay ${ }^{2}$ \\ ${ }^{1}$ Faculty Law, Muhammadiyah University of West Sumatera, Indonesia. \\ ${ }^{1}$ Faculty Law, Andalas University, Indonesia. \\ * Corresponding author E-mail: sukmarenirajab@yahoo.com
}

\author{
ARTICLE INFO \\ Keywords: \\ Corruption; Criminal law; \\ Investigation; Eradication of \\ Corruption \\ How to cite: \\ Sukmareni., Danil, E., \\ Ismansyah, Daulay, Z. \\ (2018). "Implication of \\ Regulation Authorities on \\ the Efforts to Accelerate the \\ Eradication of Corruption," \\ Hasanuddin Law Review, \\ 4(3): 356-365 \\ DOI: \\ 10.20956/halrev.v4i3.1078
}

\begin{abstract}
Investigation of corruption, as an extra ordinary crime is granted to the three institutions, namely the Police, Attorney General and the Indonesian Corruption Eradication Commission (KPK). The granting of authority to these three institutions aims to accelerate the eradication of corruption, not only detrimental to the finances and the economy of the country but has damaged the joints of life of the nation and state. The research is descriptive and uses a normative juridical approach. Aiming to find out, and analyze qualitatively the implications of regulating investigative authority over the eradication of corruption in Indonesia. The study found that all three institutions that were given the authority to investigate corruption crimes were administratively separated, but functionally these three institutions should collaborate to accelerate the eradication of corruption, but in practice this was not the case, each institution tended to be shackled by fragmentary and institutional nature. centric that does not support the eradication of corruption. This is because the regulation of the authority of each institution has not been strictly regulated, then the arrangements are not synchronized and among the existing legislation, so that there is overlap of authority due to differences in interpretation between investigators, which results in investigations not going well.
\end{abstract}

Copyright (C) 2018 HALREV. All rights reserved.

\section{Introduction}

Corruption is no longer felt as something that is only detrimental to the country's finances or economy, but should be seen as something that violates the social and economic rights of the community as part of human rights. Therefore, there are enough rational reasons to categorize corruption as an extraordinary crime, so that its eradication needs to be done in extraordinary ways and by using extraordinary legal 
instruments (extra ordinary instrument). ${ }^{1}$ Corruption is no longer a local problem, but a transnational phenomenon that affects all societies and economies that encourage international cooperation to essentially prevent and control it. ${ }^{2}$ These extraordinary ways are then manifested in the legislative policy into exceptional provisions which are deviant from the general rules of criminal law, including in the field of investigation.

To find out the development of corruption in Indonesia compared to other Asian countries, which was released by Transparency International Indonesia for the 2001-2015 Corruption Perception Index Trends, that in 2015 the Indonesian Corruption Perception Index scored 36, which means a 2-point increase (19 ratings) This score is still 4 points adrift of the ASEAN average (including Singapore), but promising if the positive trend can be maintained or even improved. ${ }^{3}$

The position of the Indonesian Corruption Eradication Commission (hereinafter, KPK), which was formed by Law No. 30 of 2002, as an alternative and independent institution that is authorized to conduct investigations other than the Police and Attorney's Office in eradicating corruption is expected to have a high ability of moral integrity; because of the fact that so far it has been described that the investigation of corruption crimes previously carried out by the Police and the Attorney General's Office, it turns out that in its implementation it creates legal problems at the level of implementation, tends not to be maximum and seems less capable in optimizing corruption. The existence of KPK is a manifestation of the legal response of the community that is legitimized by the State so that the KPK is able to play a more representative role in combating increasingly complex corruption. ${ }^{4}$ The position of the Police and the Attorney General's Office in an institutional structure is still under executive authority and having a command system that is subject to the orders of superiors, is one of the obstacles for the Police and prosecutors to be able to be objective in eradicating corruption.

In practice, there is a struggle for authority between agencies authorized to investigate criminal acts of corruption, this is caused by the absence of uniform interpretation of existing legislation, overlapping authority arrangements and legal uncertainty, or it could be due to conflicting interests. ${ }^{5}$ The climax was after the conflict of authority between the Police and the KPK in the SIM simulator case involving corrupt police officers at the National Police Headquarters, finally the President of the Republic of Indonesia Soesilo Bambang Yudhoyono, on 8 October 2012, expressed his hope that the KPK and the Police immediately renew the MoU.6 Responding to the above problems, this study tries to find out "What are the implications of regulating the authority of investigation on efforts to eradicate corruption in Indonesia?.

\section{Method}

This research is descriptive, using a normative legal approach, where the data used is secondary data consisting of primary legal material in the form of legislation relating to the regulation of the authority to investigate corruption in Indonesia, secondary legal

1 Elwi Danil, (2011), Korupsi Konsep, Tindak Pidana dan Pemberantasannya, Jakarta: PT Raj Grafindo Persada, p. 76

United Nations Convention Againts Corruption, (2003), Preambule 4.

3 Komisi Pemberantasan Korupsi (KPK) Republik Indonesia, (2015), Rencana Strategis (Renstra) KPK, Tahun 2015-2019, p. 1

4 See, Moh. Hatta, (2015), KPK dan Sistem Peradilan Pidana. Yogyakarta: Liberty, p. 37-43

5 Salahuddin Luthfie, (2011), Kewenangan Kejaksaan Dalam penydidikan Tindak pidana korupsi, Tesis, Fakultas Hukum, Pascasarjana Ilmu Hukum, Universitas Indonesia, 2011, p.41-43

6 Jan S. Maringka, (2017), Reformasi Kejaksaan Dalam Sistem Hukum Nasional, Jakarta: Sinar Grafika, p. 17 
material as legal material to clarify legal material primary in the form of books, documents, research results, etc., as well as tertiary legal material as a complement to the previous legal material in the form of a legal dictionary. Collection of legal material is carried out through document studies and literature studies. Legal materials obtained are grouped based on the problems studied (categorization) and labeled according to the problems studied, to facilitate if needed in conducting qualitative analysis, using legal hermeneutics.

\section{Regulation of the Authority for Investigation of Corruption}

\subsection{Investigation of Corruption Crimes by the Police}

The legal substance of investigating corruption is found in the provisions of Article 26 of Law Number 31 of 1999 concerning the Eradication of Corruption (1999 Corruption Law), stating that "Investigation, prosecution, and examination in court proceedings in cases of corruption, is done by law applicable criminal program, unless otherwise specified in this law". If a grammatical interpretation is made of the sound of Article 26 above, then the word "based on applicable criminal procedural law" means referring to Law Number 8 of 1981 concerning the Indonesian Criminal Procedure Code (KUHAP), as the only legal provision events that apply in Indonesia. Thus, the criminal act of investigation is carried out by investigators Article 106 to 136 of the Criminal Procedure Code, which according to Articles 1 to 5 of the Criminal Procedure Code the investigation is the authority of the police.

Then, in Article 14 paragraph (1) letter g of Law Number 2 of 2002 concerning the National Police of the Republic of Indonesia (Police Law), and states that in carrying out the task of investigating and investigating all criminal acts in accordance with KUHAP and other laws and regulations. The Criminal Procedure Code provides a leading role to the Police in investigations and investigations, so that in general the authority to conduct investigations and investigations of all criminal acts is the authority of Police. However, it still pays attention to and does not reduce the authority possessed by other investigators in accordance with the laws and regulations which become their respective legal basis.

Furthermore, in order to carry out investigative duties, the Police in general according to Article 15 paragraph (1), has the authority: (a) to receive reports or complaints; b) carry out special examinations as part of police actions in the context of prevention; c) take the first action on the scene; d) taking fingerprints and other identities and photographing someone; e) seeking information and evidence. Police actions according to the explanation in Article 15 are forced efforts or other acts according to law that are responsible for realizing orderly and upholding of the law and the establishment of public peace, while the information and evidence referred to are related to both the criminal process and the police duties in general.

\subsection{Investigation of Corruption by the Prosecutor's Office}

Article 284 paragraph (2) KUHAP jo. Article 17 Government Regulation number 27 of 1983, and Article 30 paragraph (1) letter d of Law Number 16 of 2004 concerning the Prosecutor's Office, assigns tasks and authority to the Prosecutor in addition to prosecution as the main task, also authorized to conduct investigations on certain criminal acts based on the Law ". The particular criminal act according to the explanation of the article is regulated in Law Number 26 of 2000 concerning Human Rights Court 
and Law Number 31 of 1999 concerning Corruption Law No. 20 of 2001. Thus the Prosecutor's Office is the institution authorized to deal with criminal acts corruption can act as a public prosecutor who gets the results of an investigation (BAP) from the Police regarding corruption and can also act as a direct investigator.

The authority of the prosecutor's office in investigating criminal acts of corruption is still being questioned, this can be seen from the existence of the Prosecutor's Office as an investigator in the case of criminal acts of corruption that cannot be fully understood with one opinion. There are still differences in interpretation among law enforcement officials, in its implementation there are still judges who in their decisions have not yet acknowledged the prosecutor as an investigator of corruption. The Supreme Court has provided an answer to respond to this issue by issuing an opinion or fatwa Number KMA/102/III/ 2005 dated March 9, 2005, essentially explaining that the Prosecutor has the authority to investigate corruption cases after the enactment of Law No. 31 of 1999 Jo. Act Number 20 of 2001 with the basis of Article 26 and Article 27, Article 284 paragraph (2) KUHAP and its explanation. Article 17 of Government Regulation Number 27 of 1983 Article 30 paragraph (1) letter d of Act Number 16 of 2004. Likewise, with the Constitutional Court stated that the authority of the Prosecutor in investigating corruption in Article 30 paragraph (1) letter d of the 2004 Prosecutor Law does not violate the 1945 Constitution. The reason is that the constitution does not prohibit the existence of a dual function carried out by the Prosecutor, as the president has a function as the holder of governmental power and legislator. ${ }^{7}$

\subsection{Investigation of Corruption Crimes by the Indonesian Corruption Eradication Commission (KPK)}

Article 6 of Law No. 30 of 2002 concerning the Corruption Eradication Commission (KPK Law), explicitly states that the duties of the KPK are: (1) coordination with agencies authorized to eradicate corruption; (2) supervision of agencies authorized to eradicate corruption; (3) conduct investigations, investigations, and prosecutions against corruption; (4) taking precautionary measures against corruption; and (5) monitor the administration of state government.

In carrying out the tasks of investigation, investigation and prosecution as referred to in Article 6 letter c, the KPK is given more authority beyond the investigative authority as stipulated in the Criminal Procedure Code that is owned by the Police and the Attorney General's Office, so that the KPK is called a super body institution. The authority referred to in Article 12 paragraph (1) of the KPK Law is for:

a. Tapping and recording conversations;

b. Ordered relevant agencies to prohibit someone from traveling abroad;

c. Request information from banks or other financial institutions about the financial condition of the suspect or defendant being examined;

d. Ordered banks or other financial institutions to block accounts suspected to be the result of corruption belonging to the suspect, defendant, or other related parties;

e. Ordered the leader or superior of the suspect to suspend the suspect from his position;

7 Lasmadi, S. (2010). Tumpang tindih kewenangan penyidikan pada tindak pidana korupsi dalam perspektif sistem peradilan pidana. Inovatif: Jurnal Ilmu Hukum, Vol. 2 No. 3: 33-43. 
f. Request suspect data and taxation data of the suspect or defendant to the relevant agency;

g. Temporarily suspend a financial transaction, trade transaction and other agreement or temporarily revoke the license, license and concession that is carried out or owned by the suspect or defendant, which is allegedly based on sufficient initial evidence relating to corruption that is being examined;

h. Request assistance from Interpol Indonesia or other state law enforcement agencies to conduct searches, arrests and confiscation of evidence abroad;

i. Request the assistance of the police or other relevant agencies to carry out arrests, detention, searches and confiscations in cases of corruption that are being handled.

However, in Article 38 paragraph (1) of the KPK Law and its explanation affirms that all authority relating to investigation, investigation and prosecution are regulated in the KUHAP, such as the authority to arrest, detain, search, confiscate, examine letters. Also applies to investigators, investigators and public prosecutors at the KPK. Furthermore, the KPK is based on Article 42 of the KPK Law, authorized to coordinate and control investigations, investigations and prosecutions of corruption committed jointly by people who are subject to military and general justice courts.

In the event that a corruption crime occurs and the Corruption Eradication Commission has not conducted investigation, while the case has been carried out by the police or prosecutor's office, according to Article 50 paragraph (1) of the KPK Law, the agency must notify the Corruption Eradication Commission no later than 14 (fourteen) working day as of the date of the commencement of the investigation. (2) Investigations carried out by the police or prosecutor's office as referred to in paragraph (1) must be carried out in continuous coordination with the Corruption Eradication Commission. (3) In the event that the Corruption Eradication Commission has begun to conduct investigations as referred to in paragraph (1), the police or prosecutor's office will no longer conduct investigations. (4) In the event that the investigation is carried out simultaneously by the police or prosecutor's office and the Corruption Eradication Commission, the investigation carried out by the police or the prosecutor's office is immediately stopped.

There is one more authority of the Corruption Eradication Commission which is considered to exceed the authority of the Police and Attorney Investigators, namely the authority of the Corruption Eradication Commission to take over cases that are being investigated by the Police and Attorney General's Office, as stipulated in Article 9 of the Corruption Eradication Commission Law. The Corruption Eradication Commission (KPK) argued: (a) public reports regarding corruption were not followed up, (b) the process of handling corruption crimes in a protracted or delayed manner for no reason that could be accounted for, (c) handling corruption acts aimed at protecting the real perpetrator of corruption, (d) the handling of criminal acts of corruption contains elements of corruption, (e) barriers to handling criminal acts of corruption due to interference from the executive, judiciary, or legislative; or (f) other circumstances which, according to the consideration of the Police or Attorney General's Office, the handling of criminal acts of corruption is difficult to carry out properly and can be accounted for.

Based on the description above it can be seen that among the three institutions that conduct investigations of corruption, the KPK is seen as a super-body institution with the extent of the investigative authority granted by the KPK Law, which authority is not possessed by other investigating agencies, even though the criminal acts investigated are equally corruption which is difficult to prove. 


\section{Implications for Arranging Authority for Investigation of Corruption Acts Against Efforts to Accelerate Criminal Acts of Corruption}

The problem of the authority of the investigation between the police investigator and the prosecutor's investigation began with the different interpretations of Article 284 of the Criminal Procedure Code. This article in its implementation raises dissent between the police and the prosecutor's office. On the one hand the National Police believes that if a period of two years as referred to in article 284 of the Criminal Procedure Code has been past, the police have the authority to investigate "all" criminal acts, both general crimes and special crimes, including special criminal cases. ${ }^{8}$

On the other hand, the Prosecutor's Office considers that a period of two years is only for handling cases of general crimes, meaning that any violation in the Criminal Code alone (material law) which becomes the authority of the Police if the transistor's provisions are not revoked. Although Article 284 of the Criminal Procedure Code has not been revoked the prosecutor (according to the Prosecutor's version) is the sole investigator for cases of special crimes namely economic crime, corruption and subversion. Revocation of this provision is sufficient to provide exceptions to the prosecutor as the authority holder of investigations into special criminal acts; this is explained by Article 17 of Government Regulation No. 27 of 1983 concerning the Implementation of the Criminal Procedure Code which states: "Investigation according to the provisions as referred to in Article 284 paragraph (1) of the Criminal Procedure Code is carried out by prosecutors and other authorized investigating officials based on legislation".

The struggle for authorization investigations continued, the evidence of the Police Law No. 28 of 1997 is still trying to interpret the norms contained in Article 284 of the Criminal Procedure Code by raising the provisions of article 14 paragraph (1) letter a which reads: "In carrying out the tasks referred to in article 13, the Indonesian National Police conducts investigations and investigations into all criminal cases with procedural law and other legislation. Providing a leading role to the state police in investigating and investigating all criminal acts, there appears to be a strong implicit desire from the police to obtain all investigative powers against cases that are categorized as general crimes or special crimes.

In connection with the task relationship between the police investigator and the prosecutor's investigator, a Police General who was last serving as the Head of the Metropolitan Jakarta Police should pay attention to Untung S Radjab's ${ }^{9}$ opinion that the inability of the police to carry out their duties and authority was not due to low or lack of juridical technical investigation assignments, but because of the struggle authority between prosecutors and police which leads to the struggle for sustenance and money; with the birth of the Criminal Procedure Code which is considered to have accommodated the police and the prosecutor's office in equality, it is like getting a pair of tigers in one sometimes that each target is ready to pounce on each other. Referring to Daniel S Lev's ${ }^{10}$ opinion that the relationship between police and prosecutors as a competition for authority is not solely because of fighting over power, prestige or sustenance, but because it only covers the lack of police who have not fully mastered the

\footnotetext{
Moh Hatta, Loc.Cit.

Untung S Radjab, (2003), Kedudukan dan Fungsi Polisi republik Indonesia dalam Sistem Ketatanegaraan Berdasarkan UUD 1945, Bandung: CV Utomo, p. 341
}

10 Ibid 
juridical technique of investigation coupled with the urge to monopolize the authority of the investigator. In this connection, it is interesting to understand that

"When governments tend to be more authoritarian, they will tolerate or be seen in corruption, such a government is likely to build anti-corruption institutions to manipulate access to corruption networks by emphasizing targeted authority to lower officials without known to the public". 11

According to Saldi Isra, 12 the KPK will continue to face external "disturbances" that have the potential to reduce the rate of efforts to eradicate corruption. While internally, the KPK must complete a pile of cases with limited personnel. Internal burdens can become heavier with plans to form KPK representatives in the regions, external disturbances, including: the emergence of a desire to revise the KPK Law, the KPK is still difficult to gain political support in strengthening and meeting internal needs.

KPK as an institution whose existence and authority are given by law, its position is lower than that of other institutions mandated by the constitution. The KPK has a temporary function, that is, until there is no more extraordinary state of corruption, or before the police and prosecutors can carry out their duties and authority in eradicating Corruption Crimes properly. So that if problems arise with certain parties, it could be weakened by a revision of the law and other ways, such as those carried out by the House of Representatives some time ago that want to revise the KPK Law, which was reported by some people to do weakening against the KPK.

In the implementation of this coordination and supervision, there were a number of problems, including personnel problems, if those who did this were investigators from the Police investigator and the Attorney General's loan who went to the area, and faced the regional police chief and the head of the High Prosecutor's Office who were far above their rank who carry out the coordination and supervision tasks, they will be psychologically and hierarchically difficult in the career path. ${ }^{13}$

So far, administratively KPK investigators are still dependent on their original institutions, the KPK's independent establishment requires the need for the KPK to have its own investigators, no longer borrowing from other institutions. This is very important in order to avoid the possibility of withdrawal by the originating institution of the investigator, which has a large potential to disrupt institutional independence and the independence of the function of the KPK, which can guarantee institutional work to achieve the ideal goals expected from its formation. ${ }^{14}$ This happens because investigators in the KPK generally come from police investigators and prosecutors who are elected and appointed as KPK investigators. Indeed, the KPK should have investigators appointed themselves to better protect independence in carrying out such extensive investigative assignments given to the KPK.

11 Hollyer, J. R., \& Wantchekon, L. (2014). Corruption and ideology in autocracies. The Journal of Law, Economics, and Organization, 31(3): 499-533.

12 Saldi Isra, (2017), Hukum Yang Terabaikan (Catatan Hukum Dua Tahun Pemerintahan Jokowi-JK), Jakarta: PT Kompas Media Nusantara, p.25-32

13 Febri Diansyah, Donal Fariz and Emerson Yuntho, (2011), Penguatan Fungsi Koordinasi dan Supervisi KPK, Indonesian Corruption Watch (ICW)- MSI-USAID, Jakarta, p. 17

14 Jimly Asshidiqie, (2008), Pokok-Pokok Hukum Tata Negara Indonesia, Jakarta: Bhuana Ilmu Populer, p 879880 
The disparity of the investigating institution shows that there is no synergistic and harmonious, thus impacting the ineffectiveness of the investigation of the crime itself. Police investigators who have been constitutionally from the beginning of the formation of this State have placed the responsibility of authority in the field of law enforcement, especially the investigation of corruption, institutionally very strong because it has human resources and infrastructure in all parts of Indonesia. Therefore, the hope to eradicate corruption in the country of Indonesia should strengthen the police institutionally, especially those that play a role in the process of investigating criminal acts of corruption. 15

In contrast, Jan S. Maringka argued that another solution, giving the authority to handle corruption cases only at one institution, namely the KPK. However, this authority only reaches the level of investigation and investigation minus prosecution. Prosecution is still being given to the Prosecutor's Office. This is intended to have a control mechanism in the settlement of corruption cases, so that excessive actions can be avoided in eradicating corruption. This method requires the improvement of the institutional reform of the Corruption Eradication Commission by adding facilities and personnel to reach all parts of Indonesia. This method will avoid friction between institutions in eradicating corruption so that institutional harmonization occurs in the context of eradicating corruption. ${ }^{16}$

The author disagrees with Maringka above, if giving the authority to investigate Corruption Crimes only to the KPK, it means changing the general provisions already in force in the criminal procedural law itself, which has expressly stated that the investigator is a Polri investigator and PPNS, and this will change not a few existing legal provisions. If there were some exceptions to the investigation of Corruption, it would still be logical to be aware of the principle of lex specialis derogaat lex generalis, not to completely eliminate the authority of investigation by police investigators as stated above. Hence, in order to deal with welfare crime and corporate crime and cases that complicated the verification of the role of prosecutor investigators were more professional and capable compared to police investigators. ${ }^{17}$ The problem of the investigation for the police is indeed a dilemma in spying on the burden of duty carried out by the police concerning public security and order.

Unequal granting of authority to the three institutions authorized to investigate criminal acts of corruption, creates jealousy for other institutions. The granting of such broad authority to the KPK in investigating criminal acts of corruption, creates jealousy for the Police and the Attorney General's Office. However, the criminal act that will be investigated is a criminal act of corruption, which is complicated to prove it and has a big challenge because it deals with policy makers in this country. If the Police and the Attorney General's Office are also given wiretapping and confiscation authorities such as those owned by the KPK, it will accelerate the eradication of criminal acts of corruption. The KPK alone with one head office can do a lot of hand-catching (OTT) operations against suspected corruption perpetrators, especially if the police and the Attorney General's Office which have many representatives and human resources throughout Indonesia are given the same authority, will be able to reveal more corruption cases in area.

15 M. Aris Purnomo, Eko Soponyono, (2015). Rekonseptualisasi Penyidikan TPK oleh Polri Dalam Rangka Efektivitas Pemberantasan TPK, Jurnal Law Reform, Vol. 11, No. 2, p. 232

16 Jan S. Maringka Loc. Cit, p. 58

17 Rukmini, (2003), Perlindungan HAM mlalui Asas Praduga Tak Bersalah, Bandung: Alumni, p. 119 
In connection with the formulation of the law, another problem is that if the law that has been formulated does not provide an easy solution in its application, then the legal officer must pay attention to the basis of refusal which is used as the joint of the rule and oriented on the values behind the legal provisions. It can also be said that the legal officer did not find explicit rules in the law regarding the choice of law so that he had to return to the principles which became the basis for the refusal of the law and follow those principles as a guide. 18 This must indeed be done by the three institutions investigating criminal acts of corruption in response to the current arrangements. However, there is a great hope that reformulation of criminal law policy will be carried out in the field of providing criminal acts of corruption, regulating firmly, and synchronously the authority to investigate the three investigating institutions, so as to create an arrangement that can provide certainty, usefulness and public justice.

\section{Conclusion}

The three institutions that have been given the authority to conduct investigations of corruption crimes administratively are separate separately, but functionally these three institutions should work together to accelerate the eradication of corruption in Indonesia. Nevertheless, in practice this is not the case, each institution tends to be shackled by the fragmentary and centric institutions that do not support the eradication of corruption. KPK as an extra-ordinary institution with a broader authority compared to the Police and Attorney General's Office, so it is called a super-body institution. This condition creates jealousy for other institutions in this case the Police and the Attorney General's Office, because they both deal with corruption crimes which are classified as extra-ordinary crimes, but have different powers, such as wiretapping and confiscation.

In the same way, weaknesses in the investigation of corruption in the future must be strictly regulated about the authority of each investigator, with boundaries that are clearly not abstract, integral and synchronous in their arrangements among the three laws that give authority, namely the Police Law, Attorney General Law, and KPK Law as well as the Indonesian Criminal Procedure Code (KUHAP), following the regulations in their respective technical regulations. If the arrangement is in harmony and synchronous among the existing regulations, it will be used as a guideline for the three institutions in the future, not as problematic as they are now, by revising the existing provisions or making new provisions.

18 Roeslan Saleh, (2001). Penjabaran Pancasila dan UUD 45 Dalam Perundang-undangan. Jakarta: Aksara Baru, p. 14. 


\section{References}

Elwi Danil, (2011), Korupsi Konsep, Tindak Pidana dan Pemberantasannya, Jakarta: PT RajaGrafindo Persada.

Febri Diansyah, Donal Fariz and Emerson Yuntho, (2011), Penguatan Fungsi Koordinasi dan Supervisi KPK, Indonesian Corruption Watch (ICW)- MSI-USAID, Jakarta.

Hollyer, J. R., \& Wantchekon, L. (2014). Corruption and ideology in autocracies. The Journal of Law, Economics, and Organization, 31(3): 499-533.

Jan S. Maringka, (2017), Reformasi Kejaksaan Dalam Sistem Hukum Nasional, Jakarta: Sinar Grafika.

Jimly Asshidiqie, (2008), Pokok-Pokok Hukum Tata Negara Indonesia, Jakarta: Bhuana Ilmu Populer.

Komisi Pemberantasan Korupsi (KPK) Republik Indonesia, (2015), Rencana Strategis (Renstra) KPK, Tahun 2015-2019.

Lasmadi, S. (2010). Tumpang tindih kewenangan penyidikan pada tindak pidana korupsi dalam perspektif sistem peradilan pidana. Inovatif: Jurnal Ilmu Hukum, Vol. 2 No. 3: 33-43.

M. Aris Purnomo, Eko Soponyono, (2015). Rekonseptualisasi Penyidikan TPK oleh Polri Dalam Rangka Efektivitas Pemberantasan TPK, Jurnal Law Reform, Vol. 11, No. 2 : 232.

Moh. Hatta, (2015), KPK dan Sistem Peradilan Pidana. Yogyakarta: Liberty.

Roeslan Saleh, (2001). Penjabaran Pancasila dan UUD 45 Dalam Perundang-undangan, Jakarta: Aksara Baru.

Rukmini, (2003), Perlindungan HAM mlalui Asas Praduga Tak Bersalah, Bandung: Alumni.

Salahuddin Luthfie, (2011), Kewenangan Kejaksaan Dalam penydidikan Tindak pidana korupsi, Tesis, Fakultas Hukum, Pascasarjana Ilmu Hukum, Universitas Indonesia.

Saldi Isra, (2017), Hukum Yang Terabaikan (Catatan Hukum Dua Tahun Pemerintahan JokowiJK), Jakarta: PT Kompas Media Nusantara.

The United Nations Convention Againts Corruption, (2003). Available online at: https://www.unodc.org/pdf/crime/convention_corruption/signing/Convention-e.pdf (Accessed on May 16, 2017).

Untung S Radjab, (2003), Kedudukan dan Fungsi Polisi republik Indonesia dalam Sistem Ketatanegaraan Berdasarkan UUD 1945, Bandung: CV Utomo. 